DOI:10.33099/2311-7249/2019-36-3-115-122

УДК: 355.41

Юрій Олександрович Ганненко

Микола Анатолійович Закалад

Національний університет оборони Украӥни імені Івана Черняховського, Київ, Украӥна

\title{
АНАЛІЗ ФУНКЦІОНУВАННЯ СИСТЕМИ ЛОГІСТИКИ У ПРОВІДНИХ КРАЇНАХ СВІТУ
}

У статті на основі проведеного аналізу функціонування системи логістики Збройних Сил провідних краӥн світу пропонується ї̈ удосконалення иляхом створення автоматизованої системи управління логістики.

Для ефективного управління логістичними процесами Збройних Сил Украӥни необхідне використання системного рімення стосовно формування автоматизованої системи управління логістики, вибору інформаційно-програмної платформи відповідної функціональності та масштабу для автоматизачї прочесів управління логістики, побудови інформаційної інфраструктури системи логістики, та, зрештою, - створення автоматизованої системи управління логістики Збройних Сил України.

Інформатизація має бути одним з пріоритетних напрямків роботи з підвищення ефективності діяльності логістики Збройних Сил України. Створення нових і модернізація існуючих автоматизованих систем управління логістики на основі передових інформаційних технологій, дозволить підвищити ефективність управління логістикою ЗС Украӥни, скоротити час на одержання $і$ всебічну оцінку відомостей про матеріальні засоби на всіх етапах їх руху, підвищити ефективність логістичного, медичного і фінансового забезпечення, а також покращити взаємодію з аналогічними системами краӥнпартнерів НАТО. технології.

Ключові слова: логістика, автоматизована система управління логістики, інформаційні

\section{Вступ}

Створення сучасної ефективної системи логістики Збройних Сил (далі - 3С) України набуває в сучасних умовах особливої актуальності. Динаміка бойових дій на Сході України значно підвищує вимоги до оперативності забезпечення військ (сил) матеріальними засобами і передбачає безумовну відповідність можливостей системи логістики потребам угруповань (підрозділів) військ (сил).

Постановка проблеми. Аналіз поточного стану логістики ЗС України, досвіду ведення операції об'єднаних сил (антитерористичної операції), оцінка стану сектору безпеки і оборони, виявили низку проблем, внаслідок яких неможливо належним чином впроваджувати систему логістики 3С України, а саме:

відсутність єдиної системи логістики, недосконалість системи управління логістики Збройних Сил України (внаслідок перманентного реформування існуючих та створення нових органів військового управління логістики) не дозволяють на високому рівні здійснювати заходи організації та виконання необхідних завдань логістики (матеріального, технічного та медичного забезпечення) ЗС України;

неоптимальний розподіл відповідальності та необхідних повноважень за організацію та здійснення завдань i заходів логістики у структурах органів військового управління Міністерства оборони та Генерального штабу 3С України знижує ефективність системи логістики та системи управління ЗС у цілому;

недостатній рівень постачання ресурсів для забезпечення заходів розвитку, підготовки та застосування військ (сил), надмірність обсягів та неактуальність нормативно-правової бази призводять до зниження боєздатності та ефективності застосування військ (сил);

відсутність інтегрованої автоматизованої системи управління логістики ЗС не дозволяє у повній мірі використовувати інтелектуальний потенціал органів військового управління, можливості сил та засобів логістики, раціонально управляти матеріально-технічними та іншими необхідними ресурсами i, як наслідок, не дозволяє у повні мірі використовувати бойові спроможності військ (сил);

низький рівень застосування сучасних інформаційних технологій в ЗС України.

Для ефективного управління логістичними процесами ЗС України необхідне використання системного рішення стосовно формування автоматизованої системи управління логістики (далі - АСУЛ), вибору інформаційно-програмної 
платформи відповідної функціональності та масштабу для автоматизації процесів управління логістики, побудови інформаційної інфраструктури системи логістики, та зрештою створення автоматизованої системи управління логістики ЗС України.

Ефективність зусиль “об'єднаної логістики” визначається оптимальним розподілом функцій між командуваннями, видами 3С, органами військового управління, матеріально-технічним забезпеченням, оптимальним функціонуванням виконавців заходів логістики, які у цілому утворюють єдину об'єднану систему логістики.

Інформаційно-аналітичне забезпечення процесів управління логістики - це основа своєчасного, якісного та грунтовного рішення, ефективних процесів управління та контролю. Зрозуміло, що управління всіма підсистемами логістики, виконавцями, ресурсами та забезпечення ЗС усім необхідним для їх надійного функціонування в умовах ведення бойових дій вимагають використання найсучасніших методів і засобів військової логістики, інформаційних технологій, постійного пошуку нетривіальних рішень у ході бою, коли ситуація змінюється безперервно і непередбачувано.

Аналіз останніх досліджень і публікацій. Аналіз останніх наукових досліджень і публікацій свідчить про те, що підвищенню ефективності системи логістики присвячена низка робіт попередників, які в свій час зробили вагомий внесок у розвиток теорії військової науки. Однак, аналіз запропонованих ними методик свідчить про те, що вони розглядали окремо тилове, технічне та медичне забезпечення i не були враховані чинники, які суттєво впливають на своєчасність та ефективність єдиної системи логістики, а саме використання автоматизованої системи управління логістики. Саме тому, дані методики у наявному вигляді не можуть бути використані у повному обсязі для дослідження автоматизованої системи управління логістики, але можуть бути обрані за основу для подальшого удосконалення.

Метою статті $є$ дослідження автоматизованих систем управління логістики збройних сил провідних країн світу, удосконалення системи логістики, визначення проблем та шляхів їх вирішення.

\section{Виклад основного матеріалу дослідження}

Проаналізувавши автоматизовані системи управління логістики збройних сил провідних країн світу можна виділити такі основні напрями підвищення ефективності системи логістики:

1. Для обробки гігантських потоків інформації у військових системах логістики широко впроваджуються та використовуються системи планування ресурсів підприємства Enterprise Resource Planning (ERP), системи електронних закупівель (е-procurement EP).
2. У підрозділах логістики активно використовуються інформаційні системи контролю за матеріальними потоками, відомі під назвою “систем повної видимості активів" total asset visibility.

3. Усі військові вантажі, контейнери та пакувальні матеріали оснащені пасивними радіочастотними мікрочіпами-ідентифікаторами RFID для безконтактної радіочастотної ідентифікації.

4. Використовуються стандарти планування потреб в матеріалах і концепції корпоративного планування, створюються системи управління матеріальними потоками - відбувається перехід від окремих закупівель до управління інтегрованими ланцюгами поставок (integrated supply chain management).

5. Відбуваються зміни концептуальних принципів в організації та здійсненні діяльності 3С, зміщення акцентів від управління окремими структурами до організації наскрізних динамічних функціональних процесів [5,12,13].

Основні принципи та поняття, які покладені до основи автоматизованої системи управління ресурсами підприємства (Enterprise Resource Planing - ERP-System), повною мірою збігаються із понятійним апаратом таких автоматизованих систем управління матеріальними ресурсами військового призначення, як системи командування i управління (Command \& (and) Control - C2), прийняті в арміях провідних країн світу (далі - ПКС), зокрема НАТО.

Ознаки ідентичності таких систем очевидні. Так, наприклад, система ERP позиціонується як система програмно реалізованих, автоматизованих засобів управління ресурсами підприємства, що включає управління матеріальними, фінансовими та людськими ресурсами (кадри).

$$
Z_{n}(i, j)=\sqrt[N]{\prod_{m=1}^{N} H_{n, m}(i, j)},
$$

де: $\mathrm{H}_{\mathrm{n}, \mathrm{m}}(\mathrm{i}, \mathrm{j})$ - значення i-ої характеристики, виставленої ј-ми експертами при порівнянні n-ої ERP-системи з іншими системами, підраховується по кожному рядку;

$$
Z_{\mathrm{n}}(\mathrm{i}, \mathrm{j}) \text { - середнє геометричне значень }
$$
$\mathrm{H}_{\mathrm{n}, \mathrm{m}}(\mathrm{i}, \mathrm{j})$ (обчислюється корінь $\mathrm{N}$-го ступеня 3 добутку всіх значень) і проводиться нормування, тобто приведення значень до інтервалу $[0,1]-$ кожне середнє геометричне ділиться на суму всіх середніх геометричних:

$$
X_{n}(i, j)=\frac{Z_{n}(i, j)}{\sum_{m=1}^{N} Z_{m}(i, j)},
$$

де: $\mathrm{X}_{\mathrm{n}}(\mathrm{i}, \mathrm{j})-$ нормоване значення i-ої характеристики, виставленої ј-ою кількістю експертів при порівнянні n-ої ЕRP-системи 3 іншими системами. 
Для кожної ЕRР-системи обчислюється значення $\mathrm{X}_{\mathrm{n}}(\mathrm{i})$ - порівняльної оцінки n-ої ERPсистеми з іншими системами за характеристикою i по всім М підгрупам експертів з урахуванням їх вагових коефіцієнтів:

$$
X_{n}(i)=\frac{1}{M} \sum_{j=1}^{M} X_{n}(i, j) R(j),
$$

де: $R(j)$ - нормований ваговий коефіцієнт (вага) jої кількості експертів [5].

Стосовно 3С України, в яких облік особового складу, матеріально-технічних засобів, озброєння і військової техніки та фінансових засобів досі ведеться окремо, впровадження як концепцій, так і програмних рішень ЕRР-систем $є$ нагальною та актуальною необхідністю. Очевидно, що облік вищезазначених ресурсів військових частин по всім службам забезпечення є взаємопов'язаним i потребує своєї інтеграції в межах єдиної ЕRPсистеми [4].

У ЗС провідних країн світу для розвитку інформаційної інфраструктури логістики проводяться комплексні заходи, спрямовані на модернізацію існуючих та розробку нових компонентів АСУЛ, ведуться роботи зі створення адаптивної інтегрованої інформаційної інфраструктури логістики 3 єдиним операційним середовищем і стандартизованими формами подачі інформації. За цим досвідом зроблено висновок, що цілеспрямовану логістику можна реалізувати тільки на основі сучасної автоматизованої системи на базі оборонного ITрішення ERP-класу.

За оцінкою фахівців [5,12,13], широке застосування передових інформаційних технологій в процесі створення нових і модернізації існуючих систем логістики забезпечить більш ефективне управління логістикою 3С, скоротить час на отримання інформації та всебічну оцінку відомостей щодо матеріальних та технічних ресурсів на всіх етапах руху, зменшить ризики несвоєчасного або недостатнього за силами i засобами реагування на загрози, підвищить ефективність та взаємодію логістичних підрозділів військових формувань ЗС України.

Світова тенденція по створенню великомасштабних автоматизованих систем для збройних сил з управління оборонними ресурсами у більшості провідних країн світу (членів НАТО) бере свій початок 3 другої половини 90-х років і полягає у поетапній модульній автоматизації управлінських процесів та інтеграції модулів в загальну функціональну інформаційну систему на одній програмній платформі ERP-класу. Така система об'єднує в єдиному програмному середовищі та інформаційному просторі найбільш важливі процеси забезпечення життєдіяльності, розвитку та застосування збройних сил (логістичне забезпечення, фінансова діяльність, менеджмент особового складу, ведення організаційної структури, оборонне планування, управління інфраструктурою тощо).

Автоматизовані логістичні системи (далі АЛС) ЗС провідних країн світу створюються у відповідності до вимог стосовно функціональності, архітектури, процесів, процедур та стандартів НАТО та враховують основні вимоги до військових логістичних концепцій таких як:

"Мережецентричне логістичне забезпечення" (Network Centric Logistics - NCL);

“Об'єднана логістика" (Joint Concept for Logistics - JCL);

“Загальна видимість ресурсів логістичного забезпечення" (Joint Total Asset Visibility - JTAV);

"Цілеспрямоване логістичне забезпечення" (Focused Logistics);

"Чутливе i швидко-реагуюче логістичне забезпечення" (Sense and Respond Logistics )"

"Всеохоплююча логістична готовність" (360 Logistic Readiness) та інші.

Розвиток інформаційних технологій, а також вищезазначені концепції сформувало погляди командування збройних сил США щодо створення i впровадження автоматизованої системи управління логістики.

До числа основних завдань АСУЛ, на погляд експертів [1,2,18], входять:

взаємодія і інтеграція інформації об'єднаних і видових систем забезпечення збройних сил, включаючи систему постачання зброї i матеріальних засобів, фінансового, медичного, технічного забезпечення і перевезення;

взаємодія інформаційних систем логістики країн-членів НАТО, а також союзників США, під час спільного врегулювання конфліктів і криз;

взаємодія процесів забезпечення угруповань сил i оперативного управління ними, а також надання можливості командуючим оперативними формуваннями вибору з більшого числа тактичних варіантів дій;

планування логістики;

забезпечення доступу до постійно обновлюваної інформації від різних джерел централізованої бази даних логістики (відстеження запасів, стану і місця розташування боєприпасів, ПММ та іншого майна);

централізація інформації про потреби бойових підрозділів у матеріальних засобах (далі - Мт3);

взаємодія 3 постачальниками Мт3 i підрядниками 3 доступом посадових осіб до постійно підтримуваної загальної бази забезпечення і системам електронної комерції [7].

У межах досягнення намічених цілей за останні роки значних змін зазнала організаційна структура логістики збройних сил США i, перш за все, сухопутних військ.

На даний час $\mathrm{y}$ збройних силах США реалізується ініціатива “Логістика майбутнього", активно впроваджується система автоматичної ідентифікації всієї номенклатури предметів постачання на основі штрих-кодів, активних i 
пасивних радіочастотних міток, а також систем супутникової навігації транспортних засобів. 3 метою поліпшення показників своєчасності i якості регламентного обслуговування і ремонтних робіт впроваджують програми повного автоматизованого забезпечення життєвого циклу озброєння і військової техніки і їхнього забезпечення CALS (Continuous Acquisition and Life-cycle Support). Докладено значних зусиль для досягнення уніфікації технічного забезпечення i функціонально-технічної сумісності основних вузлів, агрегатів і механізмів. На цій основі створюються модульні ремонтно-відбудовчі комплекти запчастин, інструмента і приладдя.

Організаційно-технологічна структура перспективної системи логістичного забезпечення на тактичному рівні потребує створення підрозділів автоматизації, відповідальних за технічне обслуговування і ремонт комп'ютерних систем, усунення неполадок i коректування програмного забезпечення інформаційних систем озброєння та військової техніки.

Прогрес у розвитку систем автоматизації управління логістики особливо очевидний на прикладі повітряних сил, де подібна система базується на системі бойового управління експедиційними силами ECSS (Expeditionary Combat Support System), підсистемою якої $\epsilon$ система відстеження потоків матеріальних запасів AMT (Asset Marking and Tracking).

Також відмічається, що ECSS - це, по суті, АCУ логістичного забезпечення, що дозволяє управляти матеріальними ресурсами в режимі часу, близькому до реального, зводячи у єдиний процес усі заходи логістичного забезпечення 3 відображенням єдиної повної картини логістичної обстановки. Вона $\epsilon$ основою експедиційного i “мережецентричного" логістичного забезпечення XXI століття. За досвідом експлуатації ECSS час вирішення завдань логістики, на які раніше було потрібно близько 1 год., скоротився до 15 хв.

“Загальна видимість ресурсів" забезпечується системою АМТ, що включає автоматичну ідентифікацію і радіочастотне маркування більш ніж 12,4 млн. предметів постачання. На сьогодні у межах цієї системи обслуговуються понад 700 тис. предметів постачання.

Зазначені системи дозволяють здійснювати забезпечення всіх існуючих у світі угруповань повітряних сил США на основі єдиного планування, оптимізації ресурсів (ERP) та на основі єдиних пріоритетів. Раніше даний процес відбувався на декількох підпорядкованих рівнях зі своїми пріоритетами на кожному 3 них $[3,8,15,16,19]$.

Одне 3 технологічних нововведень демонструє з 2010 року програма TEMP (Tactically Expandable Maritime Platform) з розробки модулів на основі стандартних морських контейнерів для реалізації функцій логістичного забезпечення. На їхній базі планується створити модулі різного призначення: організації зв'язку і управління; збору і обробки інформації; забезпечення енергією (паливом); реалізації систем захисту (самооборони); ремонту $\mathrm{i}$ обслуговування ОВТ; медичного забезпечення та iH.

Особливий інтерес представляють дві концепції: “модульний морський склад” (Modular Sea Depot) і “модульна морська база” (Modular Sea Base). Головна ідея цих концепцій у можливості створення великої автономної плавучої логістичної інфраструктури морського базування iз модульних контейнерів-модулів. Наприклад, структура $з$ десяти модулів може утворити злітнопосадочний майданчик для вертольотів або виконувати функції паливозаправників для десантних катерів, катерів сил спецоперацій, а також для інших малорозмірних кораблів у прибережній зоні.

Планується, що за допомогою контейнерних модулів можна буде зібрати велику базу для забезпечення дій об'єднаних американських експедиційних сил. Подібна морська рухома база забезпечить розміщення і дії всіх платформ і носіїв зброї, включаючи літаки палубного і наземного базування. При цьому вона буде мати необхідні морехідні якості, вантажопідйомність, стійкість і плавучість. Доставку контейнерів-модулів бази до будь-якої точки Світового океану передбачається здійснювати звичайними комерційними кораблями-контейнеровозами.

Військові експерти провідних країн світу $[1,2,7]$ вважають основними критеріями оцінки ефективності функціонування системи логістичного забезпечення наступні:

час очікування поставки (виконання заявки) - 3 моменту реєстрації замовлення в системі постачання до підтвердження про одержання замовлених ресурсів;

точність за часом поставки (виконання заявки) - в межах установленого інтервалу.

Крім того, важливими критеріями є такі:

здатність забезпечити розгортання угруповань сил (в еквівалентних формуваннях, тис. чоловік); швидкість розгортання (забезпечення мобільності) угруповань військ (сил);

здатність забезпечити автономність дій сил (тривалість бойових дій);

інтенсивність бойового забезпечення (доставки Мт3) у ході бойових дій та ін.

Характерними рисами діючих і перспективних АСУЛ стануть: найвищий рівень автоматизації всіх основних функцій; здатність виконувати безперебійне постачання i будь-які вимоги угруповань сил у надзвичайних умовах; гнучкість i адаптивність системи забезпечення.

Система логістичного забезпечення збройних сил США спрямована на повне задоволення потреб угруповань сил у всіх фазах:

розгортання в районах бойового призначення;

підготовки до перших операцій, початку бойових дій; 
забезпечення сил у ході бойових дій (постачання, перегрупування i евакуація, відновлення боєздатності);

згортання бойових дій i передислокація до місць постійного базування.

Інформатизація i роботизація збройної боротьби висувають на перший план низку питань щодо: перевезення; технічного обслуговування i ремонту; відновлення боєздатності ОВТ поряд зі збереженням актуальності медичного і іншого видів забезпечення.

Логічним напрямком у розвитку АСУЛ збройних сил США та інших країн-членів НАТО $є$, без сумнівів, впровадження i застосування принципів і методів реалізованих у системах ERPкласу. Запропонована програма створення повністю інтегрованої ЕRP-системи логістичного забезпечення припускає будівництво єдиного віртуального органу логістики (Joint Logistics Enterprise) на базі корпоративного сховища даних (EDW - Enterprise Data Warehouse), а також інтеграцію різнорідних інформаційних систем на основі WEB-технологій.

Процеси закупівель i розподілу ресурсів у сухопутних військ США до 2000-х років були роз'єднані. Даний недолік було усунено лише 3 прийняттям до експлуатації системи GCSS-A. 3 1999 року АСУЛ розвивалися на основі архітектури і з урахуванням досягнень відомої комерційної ERP-системи планування ресурсів фірми SAP (Systems, Applications and Products) версії R/3 (триланцюгова клієнт-серверна архітектура, що функціонує в реальному масштабі часу). Так, у військово-морських силах США розгорнуті три великі програми автоматизації логістичного забезпечення на основі ERP-системи SAP. На базі SAP будуються також системи прийняття рішень, аналізу і оцінки інформації (версія SAP NetWeaver BI - Business Intelligence) [10].

Глобальна АСУЛ сухопутних військ Сполучених штатів Америки GCSS-A (Global Combat Support System-Army) дозволяє мати точну, одержувану в реальному масштабі часу інформацію про ресурси, що $\epsilon$ необхідною передумовою здійснення постачання сил без часу очікування. При цьому інтегруються до єдиного комплексу системи, які традиційно базувалися на трьох різних конфігураціях апаратних засобів, використовували сім операційних систем i розроблялися на восьми мовах програмування 3 використанням п’яти мережних протоколів обміну даними. GCSS-A увібрала в себе функції колишньої системи - STAMIS (Standard Army Management Information System), об'єднала понад десяти ऑiі підсистем у межах єдиної БД i операційної системи на платформі Windows NT, i ряду інших систем.

GCSS-A забезпечує доставку до передових бойових підрозділів ПММ і боєприпасів протягом доби. Інтеграція GCSS-A 3 автоматизованою системою управління тилом вищого рівня CSSCS (Combat Service Support Command System) надає командирам повну логістичну інформацію, необхідну для прийняття ефективних рішень на полі бою. Маючи ситуаційну поінформованість, командир логістичного підрозділу здатний самостійно прогнозувати потреби забезпечуваного ним бойового підрозділу в постачанні, а також вчасно організовувати доставку i розподіл відповідних ресурсів. При цьому командир бойового підрозділу може зосередитися безпосередньо на веденні бойових дій, не відволікаючись на вирішення логістичних завдань $[5,20]$.

Отже, на думку експертів АСУЛ провідних країн світу [2,15], стратегія і тактика $є$ основою планування бойових дій, а служба логістики забезпечує засоби для їх ведення. Результат бойової операції залежить від стійкого і безперебійного функціонування логістики. Сьогодні логістика зазнає змін і розвивається під безпосереднім впливом військової стратегії, досягнення цілей якої вона покликано забезпечити.

Аналіз показує, що задовольнити наведеним вимогам можливо проведенням заходів, комплекс яких американські аналітики визначили як революцію в логістичному забезпеченні. Створення системи логістики 3 розподіленим базуванням планується шляхом:

заміни масових запасів матеріальних засобів i майна на створення умов їхньої швидкої доставки від виробників і постачальників у точній відповідності потребам замовників;

побудови єдиної системи логістики на основі інформаційних технологій i ситуаційної поінформованості;

проведення організаційної реструктуризації;

створення гнучкої системи придбання;

впровадження нових технологій.

Основні заходи щодо вдосконалення системи логістики в найближчому майбутньому полягають у наступному. Скорочення надлишкових запасів матеріально-технічних засобів за рахунок переходу від принципу накопичення всього, що може знадобитися для потреб ЗС (“just-in-case"), до принципу постачання "з коліс" (“just-in-time”), що передбачає крім зазначених концепцій також:

1) розробку i впровадження концепцій “Прискореної доставки матеріальних засобів" для CB, “Точної логістики” для морської піхоти (МП) i ініціативи управління логістики Міністерства оборони США "Пряма доставка від постачальників” (DVD - Direct Vendor Delivery) 3 метою поставок $50 \%$ усього майна, що виробляється, без складування, безпосередньо від виробника, а також проведення програм електронної комерції електронного взаємного обміну даними для укладення довгострокових контрактів, доставки майна “з коліс", вибору 
найвигідніших контрактів та вибору головного підрядника;

2) перехід 3С до системи постачання за індивідуальними замовленнями;

3) реорганізацію існуючої системи логістики i створення модульних структур сил i засобів логістики, які легко адаптуються і спеціалізуються для виконання конкретних завдань;

4) передачу багатьох видів діяльності логістики 3 Міністерства оборони до приватного сектору за умови зниження витрат і виключення додаткового ризику для ЗС (програма Міністерства оборони США залучення цивільних організацій для логістики збройних сил США ( LOG-CAP Logistic Civil Augmentation Program)).

5) модернізацію інформаційної інфраструктури логістики збройних сил США.

6) виявлення шляхів зменшення надлишкових запасів логістичного забезпечення в оперативнотактичній ланці, що знижують мобільність військ і їхню живучість, а також зниження вартості життєвого циклу об'єктів ОВТ, особливо їх експлуатації $[1,2,5]$.

Слід зазначити, що для більшості перелічених вище заходів уже розроблені відповідні інформаційні технології у провідних країнах світу $[6,9,11,14,17]$. Інформаційними технологіями в логістиці, які використовуються з 2003 року, є ті 3 них, які застосовуються під час перевезень (штриховий код, радіочастотні маркери), у системах реляційних баз даних, мініатюрних приймачах сигналів глобальної системи визначення місця розташування GPS і передавачах повідомлень про місце розташування їх носіїв, космічному i волоконно-оптичному зв'язку, ефективних засобах планування військових кампаній і операцій.

Як вважають військові фахівці збройних сил США, революція в логістиці опирається, головним чином, на вдосконалювання інформаційних систем і створення більш швидких транспортних систем меншої вартості, тому що однією 3 ключових складових у автоматизації поля бою і сил XXI століття $\epsilon$ концепція досягнення панування в ситуаційній поінформованості, тобто знання всього того, що відбувається на полі бою, місця розташування, статусу, стану ресурсів своїх сил і сил противника, пересування i прогнозу поповнення запасів кожного елемента сил. Крім того, для повноти картини логістики повинна забезпечуватися загальна видимість ресурсів об'єднаних сил (JTAV), тобто їхнє місце розташування, стан, кількість, склад та інше.

В результаті впровадження концепції збройні сили США зможуть надійно випереджати противника в циклі бойового управління i прийняття рішень i, таким чином, різко підвищити ефективність дій своїх сил.

Процес впровадження ЕRP-систем є складним та вимагає серйозної підготовчої роботи, великого обсягу знань і навичок персоналу. Для впровадження проектів доводиться вирішувати проблеми організаційного, технологічного характеру та, на жаль, долати протидію з боку співробітників організації-замовника ERPсистеми, що характерно для консервативних, бюрократичних установ, у яких персонал не зацікавлений у нововведеннях, боїться втрати свого положення або розкриття нелегальних фінансових схем, не готовий відповідати за прийняті рішення, банально не бажає навчатися та опановувати нові знання, навички тощо. Для зменшення дії вказаних негативних факторів необхідно змінити мотивацію персоналу заохочувати не за відсутність формальних помилок, а за зростання показників діяльності, також слід формувати у персоналу тверду впевненість у невідворотності новацій, підтримці проекту з боку вищого керівництва.

ERP системи дозволяють використовувати одну інтегровану програму замість декількох розрізнених. Єдина система комплексно управляє всіма сферами діяльності установи. Після впровадження ЕRP-системи в установі істотно знижується об'єм паперового документообігу, підвищується прозорість всіх процесів, інформація стає більш доступною і зручною для роботи. Крім автоматизації процесів установи, впровадження ERP-системи підвищує взаємну відповідальність всіх іiі підрозділів, сприяє підвищенню дисциплінованості співробітників.

Для керівництва ERP-система надає інструментарій для роботи 3 взаємозв'язаними показниками i стратегічного управління організацією в цілому. Зрілі ЕRP-системи сумісні 3 міжнародними стандартами якості, націлені на максимальне задоволення потреб організації в засобах управління. Нижче наведені середні значення показників підвищення ефективності діяльності установи за різними показниками при впровадженні ERP-систем [5,12].

\section{Висновки і перспективи подальших досліджень}

Створення АСУЛ дозволить досягти виконання цілей стосовно:

підвищення боєготовності військ (сил) та ресурсного забезпечення їх бойової діяльності протягом тривалого часу;

збільшення ефективності функціонування ланцюгів забезпечення, надійності постачання та його адаптивності до потреб бойових підрозділів;
скорочення
часу ремонту,

обслуговування/модернізації озброєння, військової техніки та матеріальних засобів, зменшення обсягів потрібних запасних частин та майна.

Для досягнення цілей оборонної реформи щодо високої ефективності систем управління та відповідності і сумісності перспективних Збройних Сил України стандартам НАТО у період до 2020 року, необхідно для побудови АСУ "Логістика" обрати IT-рішення, яке пройшло випробування в експлуатації збройними силами 
країн-членів НАТО. Доцільним рішенням $\epsilon$ обрання готового промислового IT-рішення ЕRPмасштабу для оборонних відомств, адаптація якого дозволяє значно скоротити строки введення у продуктивну експлуатацію та звести до мінімуму ризики впровадження та подальшого використання системи внаслідок попередньої багатократної перевірки працездатності і надійної системи супроводу.

Таким чином, інформатизація має бути одним 3 пріоритетних напрямків роботи 3 підвищення

\section{Лimepamypa}

1. Автоматизированные информационные системы, базы и банки данных. Вводный курс. Учебное пособие. -М.: Гелиос АРВ, 2002, - 368 с. 2. Ващинин И.А. Война XXI века / Зарубежное военное обозрение №5/. - М.: Воениздат, 1998. - с.2-97. 3. Ващинин И.В. Взгляды США на развитие ВВС в начале XXI века / Зарубежное военное обозрение №1. - М.: Воениздат, 1998. - с. 17- 78. 4. Гаврилов А.Б., Красинський С.В., Носик О.М., Спренне В.С. Розробка автоматизованої системи отримання, зберігання та обробки інформації про наявність, стан та рух матеріальних засобів у Збройних Силах України Харків.- Честь і закон.-№2.-2007. 5. Дэниел О'лири ЕRР-системы: выбор, внедрение, эсплуатация. Современное управление ресурсами предприятия / - М.: Вершина, 2008. 6. Емельянова И.3., Партыка Т.Л., Попов И.И. Основы построения автоматизированных информационных систем: учебное пособие. / М.: ФОРУМ: ИНФРА- М, 2005. 7. Зацаринный А.А., Ионенков Ю.С. Тенденции развития современных информационных технологий с учетом концепции сетецентрических войн // Системы и средства информатики. 2007. Вып. 17. С. 47-64. 8. Заяц В.И. Роль и место воздушного транспорта в обеспечении стратегической мобильности вооруженных сил США / Зарубежное военное обозрение - М.: Воениздат, 1999,- № 4. -с.24-89. 9. Исследование операций и АСУ. - Республиканский межведомственный научный сборник. Выпуск № 18 - К.: Вища школа, 1981. - 88 с. 10. Кравченко Ю.А. РLM-технологии в SAP: ефективності діяльності логістики ЗС України. Створення нових і модернізація існуючих АСУЛ на основі передових інформаційних технологій, дозволить підвищити ефективність управління тиловим та технічним забезпеченням ЗС України, скоротити час на одержання і всебічну оцінку відомостей про матеріальні засоби на всіх етапах ïx руху, підвищити ефективність кадрового, медичного i фінансового забезпечення, а також покращити взаємодію 3 аналогічними системами країн-партнерів НАТО.

Учебное пособие. 2009, 170 с. 11. Курбаков К.И. Автоматизированные информационные системы в производстве, маркетинге и финансах: учеб. пособие / М.: КОС ИНФ, Рос. экон. акад., 2003. 12. Кульга К.С. Особенности внедрения на предприятиях и методы интеграции $\mathrm{CAD} / \mathrm{CAM} / \mathrm{PDM} / \mathrm{FRP} / \mathrm{MRP} / \mathrm{MES} / \mathrm{PLM}$ и ERP-систем / САПР и графика. 2008. №3. С. 91-94. 13. Мартынов Д. Проблемы быстродействия систем ERP - системный кризис / Автоматизация управления компаниями. 2007. №10. С. 10-15. 14. Петров В.Н. Информационные системы. / СПб.: Питер, 2002, - с.688. 15. Резяпов Н. Основные аспекты развития системы тылового обеспечения ВС США: Зарубежное военное обозрение №3, 2012, С.24-29. 16. Резяпов Н. Развитие информационной инфраструктуры тылового обеспечения ВС США 2000 - настоящий момент: Зарубежное военное обозрение №9 2012 С.22- 31. 17. Титоренко Г.А. Автоматизированные информационные технологии в экономике: ученик // М.: ЮНИТИ, 2005. 18. Шмаков И.Г. Тыловое обеспечение сухопутных войск США / Зарубежное военное обозрение.- М.: Воениздат, 1995.- № 10. - с. 17-86. 19. Щербинин Р.В. Перспективы развития парка военно-транспортных и транспортно-заправочных самолетов США / Зарубежное военное обозрение - М.: Воениздат, 2000,- № 2. - с. 33-59. 20. Battle Command and Sustainment Support System (BCS3) [Електронний ресурс]Режим доступу до журн.: https://www.globalsecuri ty.org/military/systems/ground/bcs3.htm.

\title{
АНАЛИЗ ФУНКЦИОНИРОВАНИЯ СИСТЕМЫ ЛОГИСТИКИ ВЕДУЩИХ СТРАХ МИРА
}

\author{
Юрий Александрович Ганненко \\ Николай Анатолиевич Закалад
}

\section{Национальный университет обороны Украины имени Ивана Черняховского, Киев, Украина}

В статье на основе проведенного анализа функиионирования системы логистики Вооруженных Сил ведущих стран мира предлагается ее усовершенствования путем создания автоматизированной системы управления логистики.

Для эффективного управления логистическими процессами Вооруженньх Сил Украинь необходимо использование системного решения по формированию автоматизированной системы управления логистики, выбора информационно-программной платформы соответствующей функциональности и масштаба для автоматизации процессов управления логистики, построения информационной инфраструктуры системы логистики, и наконец - создание автоматизированной системы управления логистики Вооруженных Сил Украиньл.

Информатизачия должна быть одним из приоритетных направлений работы по повышению эффективности деятельности логистики Вооруженных Сил Украины. Создание новых и модернизация существуюших автоматизированных систем управления логистики на основе передовых информационных технологий, позволит повысить эффективность управления логистикой ВС Украины, сократить время на получение и всестороннюю оценку сведений о материальнье средства на всех 
этапах их движения, повысить эффективность логистического, медицинского и финансового обеспечения, а также улучшить взаимодействие с аналогичными системами стран-партнеров НАТО.

Ключевые слова: логистика, автоматизированная система управления логистики, информационные технологии.

\title{
ANALYSIS OF THE LOGISTICS SYSTEM IN THE LEADING COUNTRIES OF THE WORLD
}

\author{
Iurii Hannenk \\ Mikola Zakalad
}

\section{National Defence University of Ukraine named after Ivan Cherniakhovsky, Kyiv, Ukraine}

In the article, based on the analysis of the functioning of the logistics system of the Armed Forces of leading countries of the world, it is proposed to improve it by creating an automated logistics management system.

The efficient management of logistics processes of the Armed Forces of Ukraine is necessary to use a system solution for the formation of an automated logistic management system, the selection of information and software platform of the appropriate functionality and scale for automation of logistics management processes, construction of the information infrastructure of the logistics system, and, ultimately, the creation of an automated logistic management system The Armed Forces of Ukraine.

Informatization should be one of the priority directions of work on improving the efficiency of logistics activities of the Armed Forces of Ukraine. Creation of new and modernization of existing automated logistic management systems based on advanced information technologies will allow to improve the efficiency of logistics management of the Armed Forces of Ukraine, reduce the time to receive and comprehensively evaluate information about material means at all stages of its movement, improve the efficiency of logistics, medical and financial provision, and also improve interaction with similar systems of NATO partner countries.

Key words: logistics, automated logistics management system, information technology.

\section{References}

1. Avtomatizirovannyye informatsionnyye sistemy, bazy $\mathrm{i}$ banki dannykh. Vvodnyy kurs. Uchebnoye posobiye. -M.: Gelios ARV, 2002, - 368 s. 2. Vashchinin I.A. Voyna XXI veka / Zarubezhnoye voyennoye obozreniye №5/. - M.: Voyenizdat, 1998. - s.2-97. 3. Vashchinin I.V. Vzglyady SSA na razvitiye VVS v nachale XXI veka / Zarubezhnoye voyennoye obozreniye №1. - M.: Voyenizdat, 1998. - s. 1778. 4. Gavrilov A.B., Krasins'kiy C.B., Nosik O.M., Sprenne B.C. Rozrobka Avtomatizovanoö sistemi otrimannya, zberígannya ta obrobki ínformatsîi pro nayavníst', stan ta rukh materíal'nikh zasobív u Zbroynikh Silakh Ukraïni / Kharkív.- Chest' í zakon.-№2.-2007. 5. Deniyel O'liri. ERP-sistemy: vybor, vnedreniye, espluatatsiya. Sovremennoye upravleniye resursami predpriyatiya / - M.: Vershina, 2008. 6. Yemel'yanova I.Z., Partyka T.L., Popov I.I. Osnovy postroyeniya avtomatizirovannykh informatsionnykh sistem: uchebnoye posobiye. / M.: FORUM: INFRA- M, 2005. 7. Zatsarinnyy A.A., Ionenkov Y.S. Tendentsii razvitiya sovremennykh informatsionnykh tekhnologiy s uchetom kontseptsii setetsentricheskikh voyn / Sistemy i sredstva informatiki. 2007. Vyp. 17. S. 47-64. 8. Zayats V.I. Rol' i mesto vozdushnogo transporta $\mathrm{V}$ obespechenii strategicheskoy mobil'nosti vooruzhennykh sil SSHA / Zarubezhnoye voyennoye obozreniye - M.: Voyenizdat, 1999,- № 4. -s.24-89. 9. Issledovaniye operatsiy i ASU. Respublikanskiy mezhvedomstvennyy nauchnyy sbornik. Vypusk № 18 - K.: Vishcha shkola, 1981. - 88 s. 10. Kravchenko Y.A. PLM-tekhnologii v SAP: Uchebnoye posobiye. 2009, 170s. 11. Kurbakov K.I. Avtomatizirovannyye informatsionnyye sistemy $\mathrm{v}$ proizvodstve, marketinge i finansakh: ucheb. posobiye / M.: KOS INF, Ros. ekon. akad., 2003. 12. Kul'ga K.S. Osobennosti vnedreniya na predpriyatiyakh i metody integratsii $\mathrm{CAD} / \mathrm{CAM} / \mathrm{PDM} / \mathrm{FRP} / \mathrm{MRP} / \mathrm{MES} / \mathrm{PLM} \mathrm{i}$ ERPsistem / SAPR i grafika. 2008. №3. S. 91-94. 13. Martynov D. Problemy bystrodeystviya sistem ERP - sistemnyy krizis / Avtomatizatsiya upravleniya kompaniyami. 2007. №10. S. 10-15. 14. Petrov V.N. Informatsionnyye sistemy. / SPb.: Piter, 2002, - s.688. 15. Rezyapov N. Osnovnyye aspekty razvitiya sistemy tylovogo obespecheniya VS SSHA: Zarubezhnoye voyennoye obozreniye №3, 2012, S.24-29. 16. Rezyapov N. Razvitiye informatsionnoy infrastruktury tylovogo obespecheniya VS SSHA 2000 - nastoyashchiy moment: Zarubezhnoye voyennoye obozreniye №9 2012 S.22- 31. 17. Titorenko G.A. Avtomatizirovannyye informatsionnyye tekhnologii v ekonomike: uchebnik / M.: YUNITI, 2005. 18. Shmakov I.G. Tylovoye obespecheniye sukhoputnykh voysk SSHA / Zarubezhnoye voyennoye obozreniye.- M.: Voyenizdat, 1995.- № 10. - s. 17-86. 19. Shcherbinin R.V. Perspektivy razvitiya parka voyennotransportnykh i transportno-zapravochnykh samoletov SSHA / Zarubezhnoye voyennoye obozreniye - M.: Voyenizdat, 2000,- № 2. - s. 33-59. 20. Battle Command and Sustainment Support System (BCS3) [Yelektronniyresurs] /Rezhim dostupu do zhurn.: https://www.globalsecurity.org/military/systems/ground/bcs 3.html. 